\title{
公孫樹前胚期ノ核分裂二就 テ(1)
}

岛村環

TAMaki Shrmamura: A note on the mitotic division in the proembryo of Ginkgo, with special reference to a chromatin-elimination.*

Received September 4, 1931.

公採樹入前肧期形成二於テ核八付絲核分裂ニヨリテ等比級數ヨ以テソノ數 シ各核間ニ八隔膜ナク多數ノ核ガ共通ノ細胞睤中ニアル狀態シ示シ核分裂ノ際ニハ

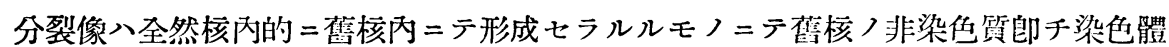
ヨ形成スル $=$ 與ラザル部分入大部分細胞質中 =消エ去ルモノノ如シ。之八分裂像及 ビ新シク生シタル娘核ノ大サガ舊核ニ比シテ著シク 小ナルコトカラ見テモ肯定シ得 ル事貸ナリ。第一圖二示セルガ如ク授精後)瘾合核（第一圖 1, 2.) ガ $85 \mu-100 \mu$ ノ直徑 7 有スル $=$ 核分裂 7 重ネル 中二次第 $=$ 小トナリ各核間 $=$ 隔膜 7 生ズル頃 $=$ 八 $20 \mu$ ノ直徑习有スルニ至ルモノナリ（第一缟、9.）。

筆者八前 = (1928) コノ核分裂殊二前肧期ノ初期、換言スレバ核つ數ガ 16 又ハ 32 個迄ノ期二於テ分裂像ノ兩極近クニ多數ノヘマトキシリンニテョク染色七ラル ル顆粒フ特ニ觀察セシガ之等つ顆粒つ核分裂ニ於ケル行動、染色體卜ノ關係二就テ 八當時未ダ不明ナリキ。其後前肧期初期ノ標品ヨ檢スル中 =前述ノ核分裂二際シテ 染色質ノ一部八娘核ニ入ルコトナク非染色質卜同栐二細胞椞中二消失スル現象 7 觀 察シコノ現秘ガ所謂 Chromatin-elinination** ナリト思ハルルラ以テ以下核分裂ノ 諸期ニ於ケル染色質ノ行動习記述セントスルモノナリ。固定液ニプアン液、フレミ ング中液ヨ用中染色ハハイデンハインヘマトキシリンフ使用セリ。

前期。核分裂前期ニ於テ大ナル核ノ一局部二染色質ガ集マリテスパイリームヨ形 成スルモノニシテ核ノ大部分卜染色體形成ノ部分卜著シク區分七ラル、ヨ岂儿（第 一圖 4,-8.)。スパイリーム八細長ク旋尞シテ密二凝着シ細クシテ單條ナルカ複條 ナルカ沈定二苦シムモノナルモ䚋察セル範園內ニテハ未ダ複保ノ形ヨ示セルコトナ

(1) 本論文; 要旨 八昭和六年十月三十一日京都二於テ開催七ラレタル 日本遗傳學會第四包 犬會ニテ講演セリ。

* Contributions from the Divisions of Plant-Morphology and of Genetics, Botanical Institute, Faculty of Science, Tokyo Imperial University, No. 104.

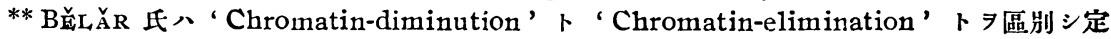
義七り、筆者八同氏/定義二從七此/語 $尹$ 使用七リ。BĚL ĽR；(1928), 頁 102 參照。 
第一圖前胚期二於ヶル核ノ大少, 比較

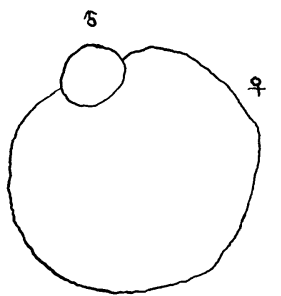

1

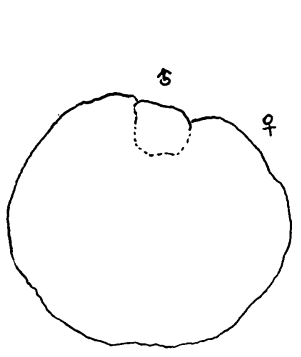

2

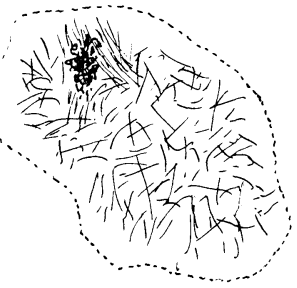

4

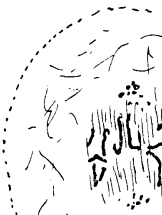

$\because<$
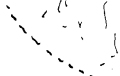

3

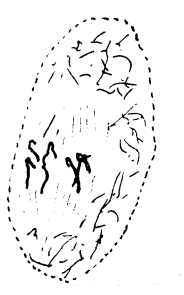

5

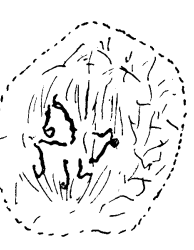

G

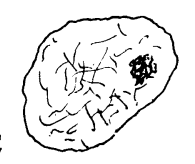

8

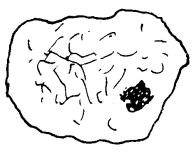

7

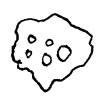

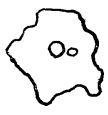

9

Fig. I. Comparison of the successively decreasing sizes of nuclei during the first 7 divisions in proembryo. 1,2. Fusion nuclei. 3. Second mitosis of proembryo, showing a large mitotic figure in the nucleur cavity, whose outline is indicated with dotted line. 4. Third mitosis of proembryo, corresponding Fig. II. 1. Spireme in localized position. 5,6. Fourth mitosis. 7,8. Prophase of fifth mitosis. 9. Nuclei after seventh nuclear division.

キヨ以テ中期ノ核板=配布スル頃マデ單條ナリト思考七ラル。第二圖 $2 \mathrm{a}, 2 \mathrm{~b}$, 八連 續セル二切片ヨ示シ第二圖 1a, 1b. 1c，八相連穦七ル三切片ヨ示ス。之等ノ圖二於 テ紐猋ノ部分ガスパイリームニテ、黒色ニ色ヅケタル部分ハヘマトキシリンニテ染 色七ラル、問題ノ染色質ナリ紡鍾體モ之等スベテハ核內的二形成出現セルモノト思 ハル、スパイリームガ毞ダシク旋卷セル スパイリームトノ比八分裂ノ他ノ期 =比シテ顆粒ガ著シク多大ナルコトヨ認メラル ベシ、顆粒ノ位置ハスパイリームノ周圍二繞集シ紡鍾體內二散布セリ、此點二於テミ トコンドリア並ニプラスチツドトハ異ナル位置ニアリ。(第二圖 1.2. 第六圖版 1.2.) 中期。染色體入核板二配置七ラル、ソノ形 $L$ 字形ノモノ多ク往々染色體ノ一部 分八長ク極二近キ處マデ延ビタルモノアリ染色體ノ太サハスパイリーム期及ビ後期 ノモノニ比シテ倍程ノ太サニテ縱裂入明ラカニ觀察シ得ザルモ太サョリシテ縱裂ス 


\section{第二圖 公孫樹入前胚期=於ヶル染色質消㪰}

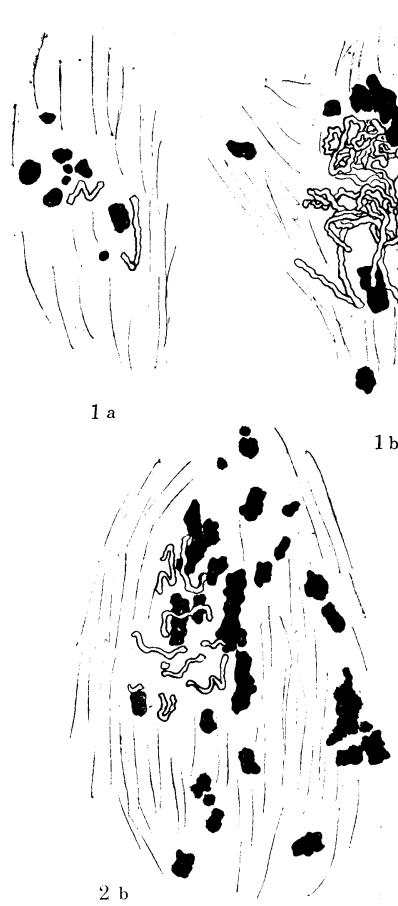

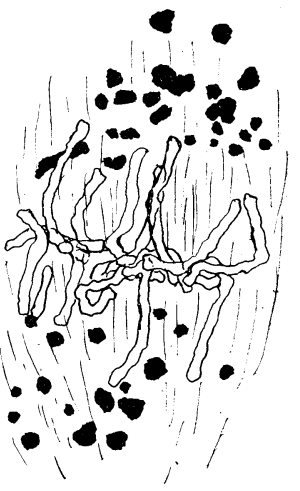

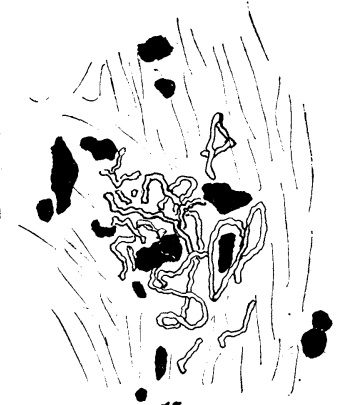

$1 \mathrm{c}$

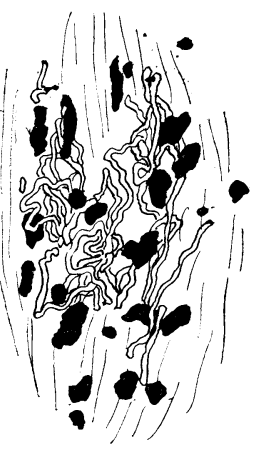

2 a

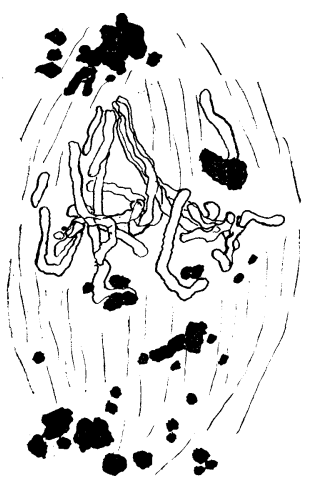

4

5
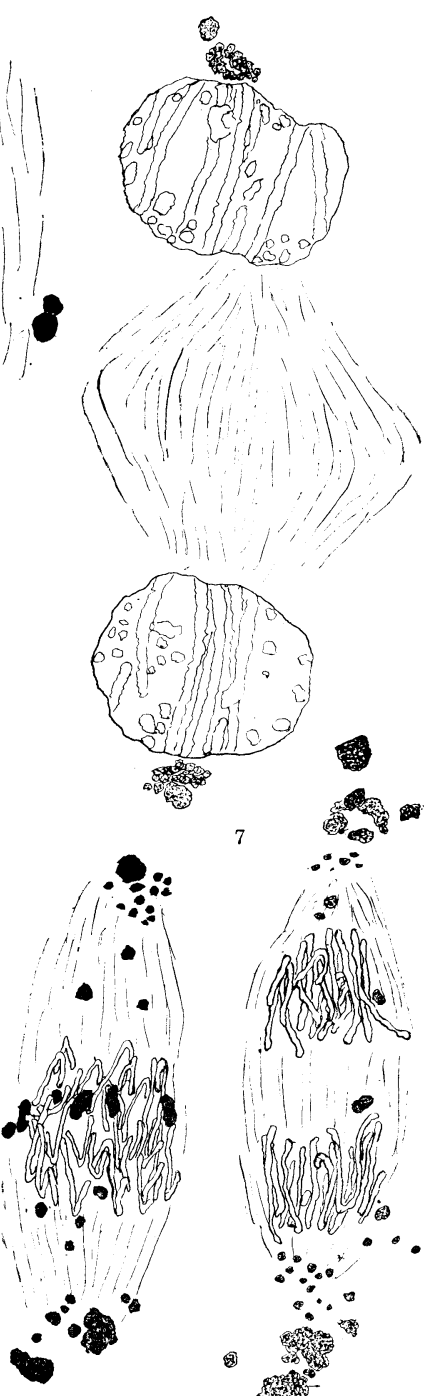

Fig. II. Chromatin-elimination in the proembryo of Ginkgo

1. Prophase, spireme with the elimination-chromatin masses (black). a, b, c. are consecutive sections. 2. Prophase, later spireme stage with the elimination-chromatin masses closely associated with spireme thread. a, b. are from consecutive sections. 3,4 . Chromosomes forming nuclear plate, while elimination-chromatin masses (black) being distributed in polar regions. 5. Farly anaphase. 6. Anaphase; among the chromosomes some elimination-chromatin masses are found. 7. Iate telophase, groups of the elimination-chromatin masses are found outside of the daughter nuclei. (ca. $\times 625)$. 
ベキモノト思ハル。コノ期ニ於テノ不規則形ノ染色性顆粒ハスパイリーム期 =比ス レバ數少ク位置八兩極ニ近クアルモノ又八染色體ノ間二散在セルモノ、兩極へ向ツ テ移リ行ク中間ニアルア示スモノ多シ。(第二圖 3,4.) (第六圖版 3.)

後期。縱裂シタル染色體ガ网極ニ向ヒテ離レ行ク際ニハ $\mathrm{V}$ 字形ノモノョリモ $\mathrm{J}$ 宇形ノモノ多ク觀察セラル。極=近クナル＝從ヒテ極つ側＝各染出體八極集ノ狀態 ヨ示ス。コノ期ノ前本二於テハ (第一圖 5.) 染色临つ顆粒八染色體つ间二介在スル モノアルラ見ルモ概シテコノ期ニ於ケル染色悱顆粒つ位置八兩極近ク集リテ塊狀 ナスモノト形小ニシテ染色體群ト塊狀ノモノトノ間二散布セルモノト大體二ツ二區 別セラレ何レモ染色體群ヨリ極近ク二存スルラ見ル、染色體群ガ 两極二近ヅク期 ヨリ塊狀トナレル顆粒ハヘマトキシリンニヨリ染マルコトラ減泣喑蓝色ヨリ灰色卜 ナル。(第二圖 6.) (第六圖版 4,5.)

終期。娘核ノ核膜 リボン爿染色質ヨ見ル、コノ期二核膜外ニヘマトキシリンニテ良ク染色セザル灰色

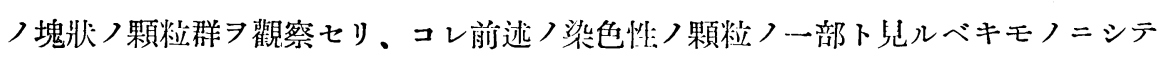

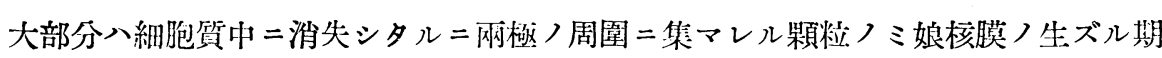

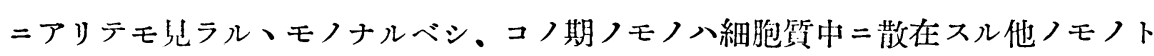

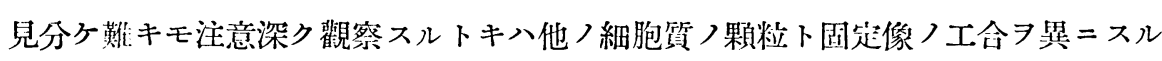

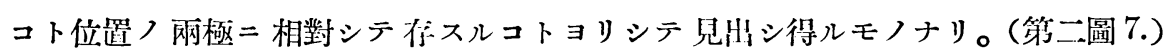
(第六圖版 6.)

上述ノ觀察ヨリ染色體以外二核分裂=際シテ現ハル、染色性顆粒 $/$ 存在及ビ核分 裂ニ於ヶル行動 大部分八分裂終期前 =消去スルモノナリ。カク核分裂つ際疑微鏡的=觀察シ得儿染

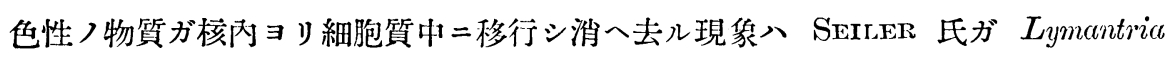
dispar, Fumea casta, Solenobia pineti 等二就テ觀察シタル染色質消棄 (Chromatinelimination）ナル現像アリ。䇤者八公棌樹ノ前肧期ノ核分裂ノ際二モ染色質消寨行 ハレ上述染色性顆粒 7 elimination-chromatin ト見做サントス。郎チ SEILER 氏ガ

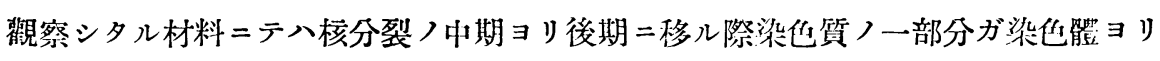
取り殘サレ逐二細胞質二渻エ失七ルモノナルガ、公孫樹ノ場合モヤハリ一種ノ染色

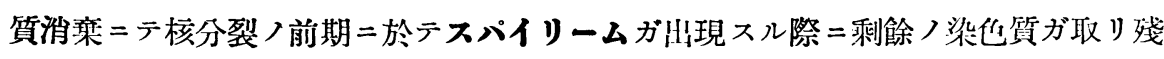
サレ染色體卜區別セラレ終期＝至ルマデ染色體卜同ジク兩極二分配セラレ後消失ス ルモノナリ。前胚期形成ノ際核ノ數ノ菂加二件ヒテ核ノ大サ八次第二小トナル。而 


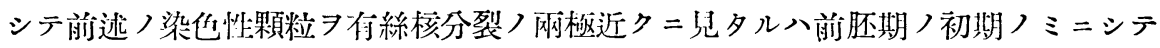
分裂像ノ大ナル時=限ラル、ガ故二前肧期ノ初期ノ核ノ大サノ變化卜該染色質消媇

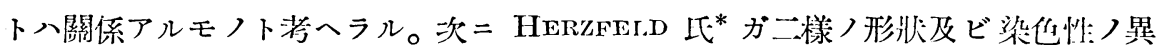

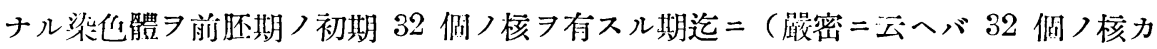

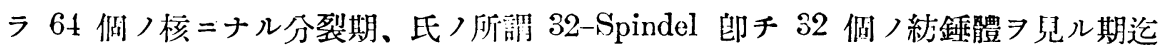

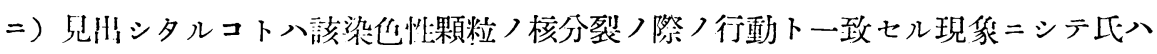
筆省ガ elimination-chromatin トセシ該染色性顆粒ヨ染色體トシテ觀察セルモノナ ルベシ。

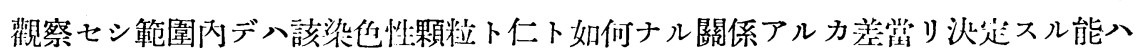
ズ、以上前胚期ノ初期 =於ケル核分裂二際シテ觀察シタル染色性顆粒二就テ概要 述ブ。

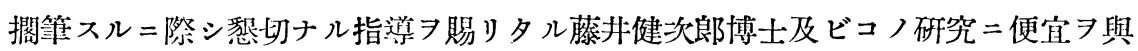

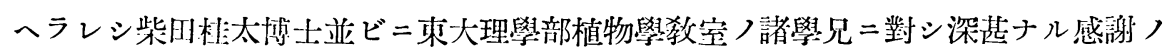
意习表ス。

昭和六年九月

東京帝國大學理學部植物學呚室 $=テ$

\section{Résumé}

1. During the successive division of nuclei in the formation of proembryo of Ginkgo the size of nucleus decreases with each division, the fusion nucleus being $85-100 \mu$, while the nucleus after seventh division $20-25 \mu$ in diameter.

2. During the prophase of the nuclear division of the early proembryo, considerable amount of deeply stainning basophilic granules are found among the spireme thread. They are neither of a definite form, nor of a constant number and are distinguished from the mitocondria or plastids by the fact that they are found only in the 'atractoplasm '** (spindleplasm, 'Spindelraum'). These granules represent chromatin which is eliminated during the prophase. As the chromosomes form the equatorial plate these eliminated chromatin granules are found scattered mostly toward both poles, and in a later stage, they partly form larger masses of less basophilic nature, and smaller fragments, both finally disappearing.

*同氏論交 (HERZFELD, 1928b.) , Fig. 2, ，Abb. 1, 2, 八本諭交／第二圖、1，2，八分 裂期、Fig. 7，ノAbb. 2 八本諭交第二圖， 5，八分裂期二相當スルモノブラン。

** Atractoplasm; $\alpha \tau \rho \alpha \kappa \tau 08$, spindle. first used by FuJII (1931) 
3. The chromatin-elimination in mitotic division in the proembryo is found only in its early developmental stage, in which the mitotic figures are of huge dimentions. The writer observed the phenomenon up to the 32-nucleate stage. It seems that the chromatinelimination has a close relation with the diminution of the nucleus.

4. The relation between the basochromatic elimination-granules and the nucleoli is not yet clear.

\section{文獻}

BĔLǍR, K., (1928) Die cytologischen Grundlagen der Vererbung. Handb. d. Vererbungswiss. I,fg. 5. Berlin.

FuJII, K., (1931) Cytology, present and past. (Japanese) Saibogaku no kwako oyobi genjo, Iwanami. Tokyo.

HERZFELD, ST., (1927) Beiträge zur Kenntnis von Ginkgo. Jahrb. f. wiss. Bot., 66, Ht. 5 .

(1928a) "Nachtrag." Jahrb. f. wiss. Bot. 67, Ht. 5.

(1928b) Ueber die Kernteilungen im Proembryo von Ginkgo biloba. Jahrb. f. wiss. Bot., 69, Ht. 2.

SFILER, J., (1914) Das Verhalten der Geschlechtschromosomen bei Lepidopteren. Arch. f. Zellforsch. 13, Ht. 2.

(1923) Geschlechtschromosomen-Untersuchungen an Psychiden. IV. Die Parthenogenese der Psychiden. Zs. f. ind. Abst.- u. Vererbgs1. 31.

Shimamura, T., (1928) On the formation of proembryo of Ginkgo biloba I. Bot. Mag. Tokyo. 42. No. 494.

\section{Explanation of Plate VI}

A11 figures are microphotos taken with the aid of LEITZ "Makam", using LEITZ achromatic objective $\frac{1}{12}$ and 'periplan' ocular 8. ca. $\times 800$.

Fig. 1. and 2. Prophase, spireme with the elimination-chromatin masses.

Fig. 3. Metaphase, Chromosomes forming nuclear plate, elimination-chromatin masses being distributed toward polar regions.

Fig. 4. Early anaphase, among the chromosomes some elinination-chromatin masses are found.

Fig. 5. Anaphase. Various sizes of the elimination-chromatin masses are observed near the polar regions.

Fig. 6. Later telophase, groups of the elimination-chromatin masses found outside of the daughter nuclei. 
植物學雜誌第忛十五卷第六圖版
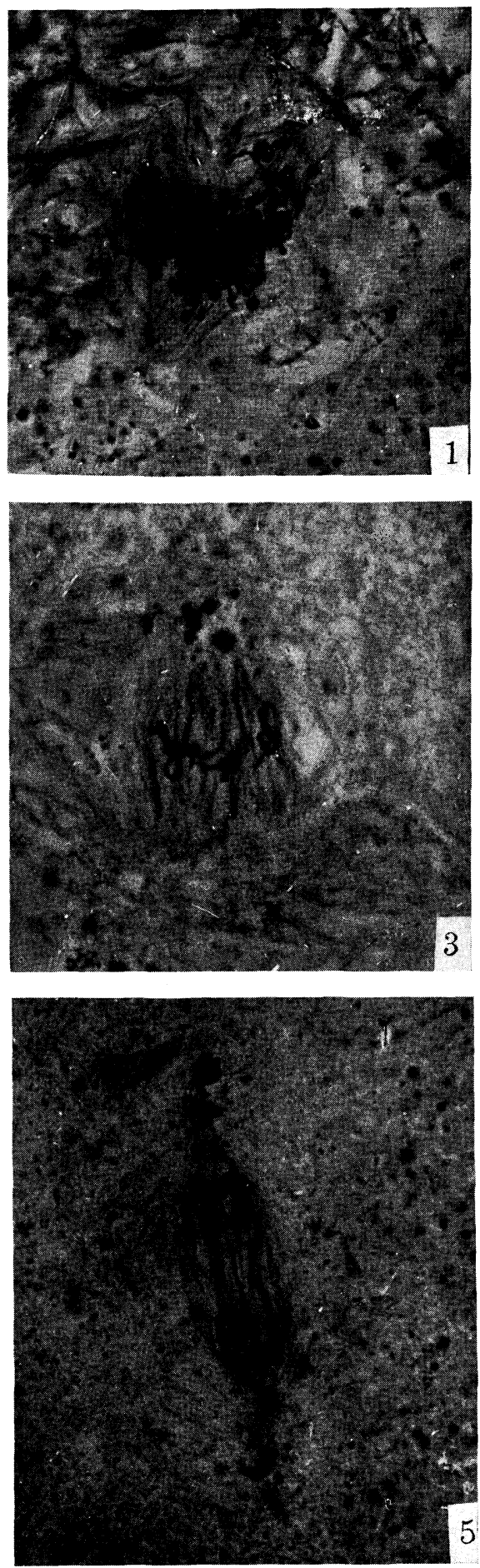

T. Shimamura Photo.
Bot. Mag. Tokyo, Vol. XI, , Pl. VI.
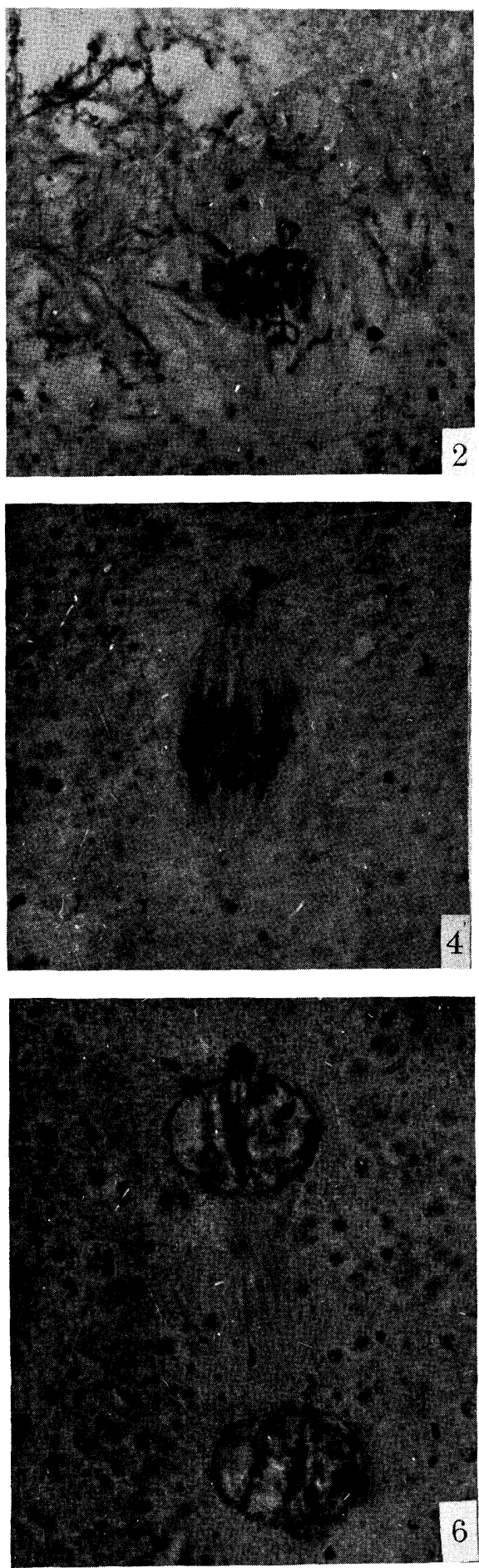

T. Shimamura-On Ginkgo. 